\title{
Recent Advances in Sorghum Genetic Enhancement Research at ICRISAT
}

\author{
Are Ashok Kumar ${ }^{1 *}$, Belum Venkata Subba Reddy ${ }^{1}$, Hari Chand Sharma ${ }^{1}$, Charles Thomas Hash ${ }^{1}$, \\ Pinnamaneni Srinivasa Rao ${ }^{1}$, Bhavanasi Ramaiah ${ }^{1}$, Pulluru Sanjana Reddy ${ }^{2}$
}

\author{
${ }^{1}$ International Crops Research Institute for the Semi-Arid Tropics (ICRISAT), Patancheru, India; ${ }^{2}$ Directorate of Sorghum Research, \\ Rajendranagar, Hyderabad, India. \\ Email: a.ashokkumar@cgiar.org
}

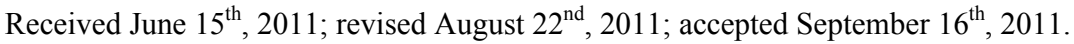

\begin{abstract}
Sorghum is one of the most important cereal crops widely grown for food, feed, fodder/forage, and fuel in the semi-arid tropics of Asia, Africa, the Americas and Australia. The global sorghum areas remained static as the increased area in Africa compensated the area loss in Asia. Inspite of rapid decline in sorghum area in Asia due to competition from other remunerative crops, sorghum grain production levels have not declined at the same rate owing to adoption of high yielding hybrids. Though impressive gains have been made in improving productivity levels, biotic and abiotic challenges such as shoot fly, stem borer, grain molds, and terminal drought stress continue to haunt the sorghum growers across the world. International Crops Research Institute for the Semi-Arid Tropics (ICRISAT) and the respective national programs are working on genetic enhancement of sorghum for high yield; shoot fly, and grain mold resistance, and sweet stalk traits. In addition, research focus at ICRISAT also includes adaptation to postrainy season, terminal drought tolerance, and increasing micronutrient contents (Fe and $\mathrm{Zn}$ ) in grain. Genetic and cytoplasmic diversification of hybrid parents and varieties for key traitsis critical for sustaining the productivity gains. The grain and stover quality requirements of different market segments needs special attention in sorghum improvement research to enhance its market value. This paper analyses the progress made in sorghum improvement research at ICRISAT in partnership with national programs in recent years and the way forward.
\end{abstract}

Keywords: ICRISAT, Sorghum, Genetic Enhancement, Grain Yield, Shoot Fly, Grain Mold, Drought, Biofortification

\section{Introduction}

Sorghum is fifth most important cereal crop globally and is the dietary staple of more than 500 million people in 30 countries. It is grown on $40 \mathrm{~m}$ ha in 105 countries of Africa, Asia, Oceania and the Americas. Africa and India account for the largest share $(>70 \%)$ of global sorghum area whileUSA, India, Mexico, Nigeria, Sudan and Ethiopia are the major sorghum producers (http://faostat. fao.org/site/567/default.aspx\#ancor verified on July 4, 2011). It is the third most important grain crop in U.S. Other sorghum producing countries include Australia, Brasil, Argentina, China, Burkina Faso, Mali, Egypt, Niger, Tanzania, Chad and Cameroon. Sorghum grain is used mostly for food purposes (55\%), consumed in the form of flat breads and porridges (thick or thin); stover is an important source of dry season maintenance rations for livestock, especially in drylands; it is also an important feed grain (33\%), especially in the Americas [1].
Sorghum area, production and productivity trends indicate that, globally sorghum area increased from 45 $\mathrm{m} \cdot \mathrm{ha}$ in $1970 \mathrm{~s}$ to $51 \mathrm{~m} \cdot \mathrm{ha}$ in $1980 \mathrm{~s}$. Later on, there was a fluctuation by 4 to $10 \mathrm{~m} \cdot \mathrm{ha}$ in area in the next two decades but reached to $40 \mathrm{~m} \cdot$ ha by 2009 . The productivity increased from $1200 \mathrm{~kg} \cdot \mathrm{ha}^{-1}$ in $1970 \mathrm{~s}$ to $1400 \mathrm{~kg} \cdot \mathrm{ha}^{-1}$ in 2009. Adoption of improved sorghum cultivars and management practices contributed to the productivity gains though large differences exist in different parts of the world for sorghum productivity (Figure 1) [2].

Sorghum is a self-pollinating, diploid $(2 \mathrm{n}=2 \mathrm{x}=20)$ with a genome, about $25 \%$ the size of maize orsugarcane. It is a 44 plant with higher photosynthetic efficiency and higher abiotic stress tolerance [3,4]. Its small genome $(730 \mathrm{Mb})$ makes sorghum an attractive model for functional genomics of $\mathrm{C} 4$ grasses. Drought tolerance makes sorghum especially important in dry regions such as northeast Africa (its center of diversity), India and the southern plains of the United States [5]. Genetic variation 

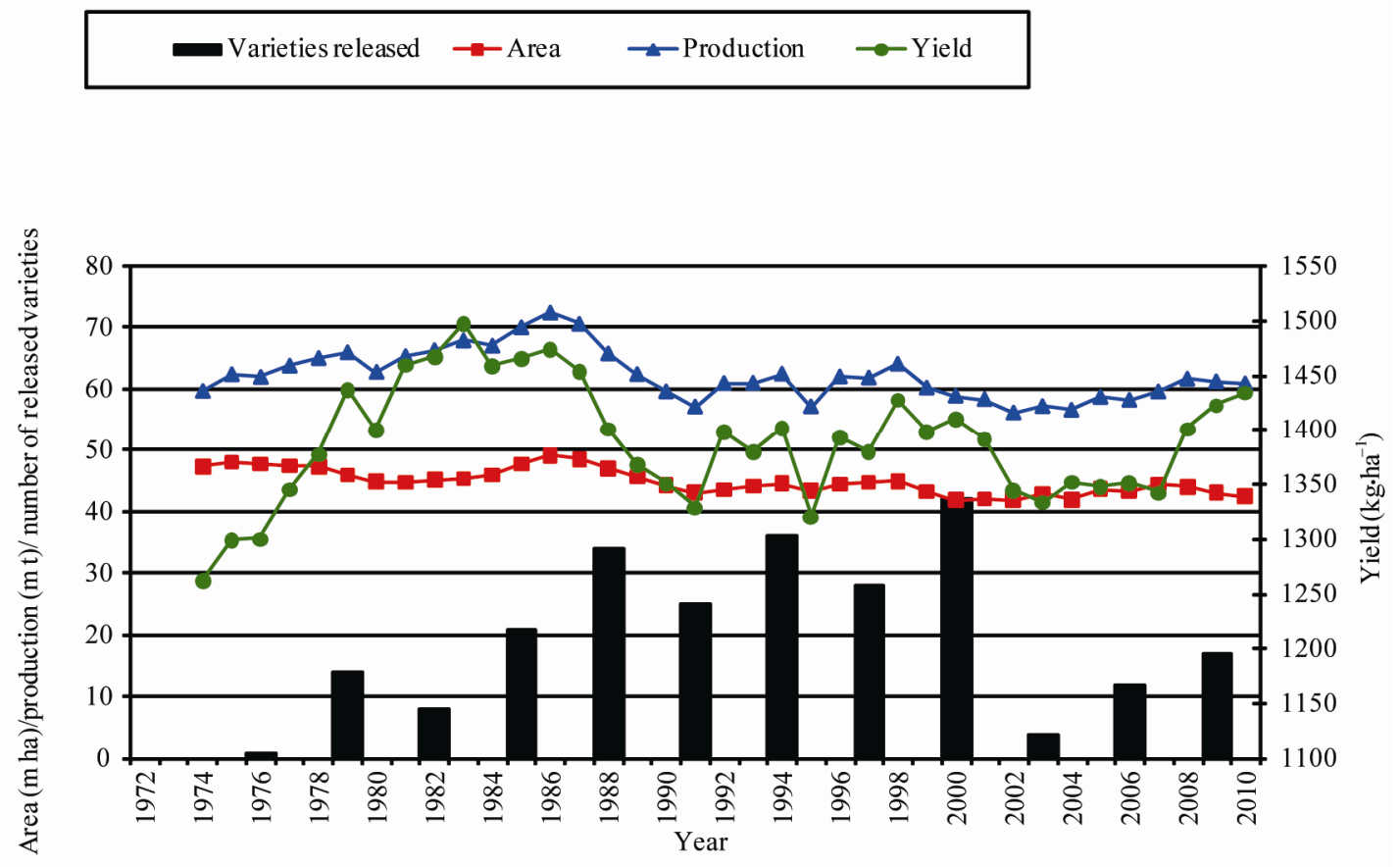

Figure 1. Three-year moving average for sorghum area, production, yield; and number of released varieties (3-years total) based on ICRISAT-bred material globally.

in the partitioning of carbon into sugar stores versus cell wall mass, and in perenniality and associated features such as tillering and stalk reserve retention, make sorghum an attractive system for the study of traits important in perennial cellulosic biomass crops [6]. Its high level of inbreeding makes it an attractive association genetics system. Sorghum is one among the climate resilient crops that can better adapt to climate change conditions $[2,7]$.

ICRISAT has a global mandate for sorghum improvement research and physical mandate of semi-arid tropics (SAT) for enhancing the livelihoods of poor [8]. The total sorghum growing areas can be divided in to eight major research domains [9].

\section{Sorghum Research Domains (SRDs)}

Of the total $40 \mathrm{~m}$ ha global sorghum area, the agroecologies, growing conditions and the market requirements are quite different necessitating crop improvement for various adaptations, different uses and market preferences. Sorghum research activities at different locations over the years were conducted under the implicit assumption of eight research domains delineated as homogeneous eco-regions in terms of soil and climatic conditions regardless of national boundaries [9]. Table 1 summarizes the characteristics of these sorghum research domains (SRDs) across the world. These domains are: wide adaptability (SRD I), dual purpose with specific adaptability (SRD II), dual purpose with fodder emphasis (SRD III), forage sorghum (SRD IV), early-sown postrainy sorghum (SRD V), late-sown postrainy sorghum (SRD VI), irrigated sorghum (SRD VII) and extreme altitude sorghum (SRD VIII).

ICRISAT has one of the largest collections of global sorghum germplasm with $>36,000$ accessions in its gene bank. These accessions are maintained under short-term and long-term storage conditions and shared with research organizations globally. ICRISAT and National Agricultural Research Systems (NARS) across the sorghum growing areas are working on sorghum genetic enhancement for traits of global and regional importance. The target materials had been open-pollinated varieties in Africa whereas hybrids and hybrid parents for rest of the world. Hybrid sorghum is gradually picking up in Africa [11]. Exploitation of global germplasm accessions through systematic crop improvement programsto a large extent has contributed to development of large number of sorghum cultivars. The germplasm and improved materials developed at ICRISAT are shared with public sector and private sector partners across the globe. For e.g. during 2010, ICRISAT sent a total of 3275 seed samples of hybrid seed parents/breeding lines to 21 countries. India received 2375 samples, followed by Nigeria and other countries. Of the 2375 samples supplied in India, 888 samples were sent to public sector scientists, 1380 samples to private sector scientists and the remaining 107 
Table 1. Characteristics of sorghum research domains.

\begin{tabular}{|c|c|c|c|}
\hline Domains & Production system characteristics & Major constraints & Locations \\
\hline SRD I (wide adaptability) & $\begin{array}{l}\text { Rainy season, multi-purpose grain, } \\
\text { stalk, fodder (fodder emphasis). } \\
\text { Wide adaptability (June-August } \\
\text { sowing) }\end{array}$ & $\begin{array}{l}\text { Grain mold, shoot fly and head } \\
\text { bug }\end{array}$ & $\begin{array}{l}\text { West Africa (southern tier), India } \\
\text { (Tamil Nadu, Southern Karna- } \\
\text { taka, Andhra Pradesh) }\end{array}$ \\
\hline $\begin{array}{l}\text { SRD II (dual purpose and spe- } \\
\text { cific adaptability) }\end{array}$ & $\begin{array}{l}\text { Rainy season, dual purpose (grain } \\
\text { and fodder). Specific adaptability } \\
\text { (June sowing). Medium- to late- } \\
\text { maturing types }\end{array}$ & $\begin{array}{l}\text { Stem borer, grain mild, midge, } \\
\text { shoot fly and drought }\end{array}$ & $\begin{array}{l}\text { East and Southern Africa, India } \\
\text { (Andhra Pradesh, Northern Kar- } \\
\text { nataka, Maharashtra, Madhya } \\
\text { Pradesh, Gujarat), Latin America } \\
\text { (some areas) }\end{array}$ \\
\hline $\begin{array}{l}\text { SRD III (dual purpose, fodder } \\
\text { emphasis) }\end{array}$ & $\begin{array}{l}\text { Rainy season, dual purpose (fodder } \\
\text { emphasis). Early maturing }\end{array}$ & Shoot fly and stem borer & $\begin{array}{l}\text { West Africa (northern tier), East } \\
\text { Africa (Yemen, Somalia), India } \\
\text { (Eastern Rajasthan), Latin Amer- } \\
\text { ica (some areas), China, Iran }\end{array}$ \\
\hline SRD V (early sown post rainy) & $\begin{array}{l}\text { Postrainy (early sown-before Octo- } \\
\text { ber). Bold grain types, dual purpose }\end{array}$ & Shoot fly, charcoal rot, aphids & $\begin{array}{l}\text { India (South Andhra Pradesh, } \\
\text { South Karnataka) }\end{array}$ \\
\hline SRD VI ( later sown postrainy) & $\begin{array}{l}\text { Postrainy season (late sown-mid/late } \\
\text { October). Bold grain, photoperiod } \\
\text { sensitivity required, temperature } \\
\text { insensitive }\end{array}$ & $\begin{array}{l}\text { Shoot fly, charcoal rot, drought } \\
\text { (shallow soils) }\end{array}$ & $\begin{array}{l}\text { East Africa (Ethiopia, Sudan), } \\
\text { India (Gujarat, South Maharash- } \\
\text { tra, North Karnataka) }\end{array}$ \\
\hline SRD VII (irrigated) & Irrigated sorghum & & Iran, Egypt, Wad Medani (Sudan) \\
\hline SRD VIII (extreme altitude) & Others & & $\begin{array}{l}\text { High altitude: China and low al- } \\
\text { titude: Indonesia, Brazil, Ecuador, } \\
\text { Venezuela }\end{array}$ \\
\hline
\end{tabular}

Source: [9-10].

samples to farmers and NGOs. Fourteen sets of sweet stalk trials consisting of 423 entries were sent for evaluation in India, Philippines, Israel, Mexico, Mozambique and Mali. Further seed samples were also sent to Brazil, Mexico, U.S.A, Australia and China. During the period 1976 to 2010 , a total of 242 sorghum cultivars were released globally using the ICRISAT-bred sorghum material by private and public sector organizations including National Agricultural Research System (NARS) partners across the world (Figure 1). ICRISAT is a major repository of global germplasm collection with a total of 36,774 accessions from 90 countries [12] and the existing collections represent about $80 \%$ of the variability present in the crop [13]. Since its establishment in 1972, germplasm sources at ICRISAT have been screened and utilized in the development of high yielding male-sterile lines (CK 60, 172, 2219) and restorers (IS 84, IS 3691, IS 3541 ). They have been valuable sources for incorporateing shoot fly and stem borer resistance (IS 1082, IS 2205, IS 2312 , IS 5604, IS 5470, IS 1054, IS 18432, IS 18417 , IS 18425), midge resistance (DJ 6514, IS 3443), multiple disease resistance (IS 3547 and IS 14387), Striga resistance (IS 18331, IS 2221), drought tolerance (IS 12611 and IS 69628), high lysine content (IS 11167, IS 11758), stalk sweetness (IS 20963, IS 15428), forage quantity and quality (IS 1044, IS 1059) and salinity tolerance (IS 164, IS 19604) [12].

Sorghum improvement research program at ICRISATPatancheru, India over the years developed more than 680 A-/B-pairs and more than 880 R-lines which were trait specific [high yield, large grain, biotic stress resistance (shoot fly, midge and grain mold) and abiotic stress tolerance (drought and salinity), grain micronutrient ( $\mathrm{Fe}$ and $\mathrm{Zn}$ ) density and sweet stalk traits] for use as parents in hybrid development [14]. In some cases, the resistance sources per se were directly converted into male-sterile lines. Of late, cytoplasmic diversification and racial diversification has been given major thrust in sorghum improvement [1].

Considerable progress has been made in developing techniques to screen for resistance to four insect pests, five diseases and drought. Apart from identification of resistant germplasm sources (particularly shoot fly and midge, and grain mold), considerable information has also been generated on the mechanisms and inheritance of resistance to insects such as shoot fly (Atherigona soccata), stem borer (Chilo partellus), shoot bug (Perigrinus maidis), aphid (Melanaphis sacchari), midge 
(Stenodiplosis sorghicola) and head bug (Calocoris angustatus) [15]. Glossy trait at the seedling stage to select for resistance to shoot fly, short and tight glumes for midge resistance and long glumes for head bug resistance have been identified as marker traits. Similarly grain hardness, flavan-4-ols in the grain and loose panicles helps in reducing damage by grain molds [16]. While diversifying sorghum hybrid parents, both geographical and racial diversity were successfully captured. The variation in caudatum race being captured for a long time now and more emphasis is given to exploit guinea and durra races in recent years. Efforts are underway to diversify hybrid parents for shoot fly resistance (SFR) and grain mold resistance (GMR) by introgressing genes from new and diverse sources of resistant germplasm lines, guinea race in particular. Postrainy season adapted sweet sorghum parental lines development is in progress. Some of the more recent advances in sorghum improvement research at ICRISAT-Patancheru, India are summarized below:

\section{Hybrid Parents Improvement for Rainy Season Adaptation}

Sorghum grain produced in rainy season in India and other Asian countries is not always preferred for human consumption if grain gets molded especially when high rain fall occurs during grain development stage. Most of the mold-affected grain goes for poultry feed or for industrial uses. However, rainy season stover is important as animal feed. The research targets are fixed based on the crop utilization and the performance of popular checks in a given ecology. For e.g. the research target for India is to develop hybrid parents that yield grain $15 \%$ to $20 \%$ higher than the commercial hybrid CSH 18 (4.5 $\mathrm{t} \cdot \mathrm{ha}^{-1}$ ) and fodder about $20 \%$ higher compared to CSH 18 $\left(13 \mathrm{t}^{-h a^{-1}}\right)$.

\subsection{Grain and Fodder Yields, Height and Maturity}

In addition to dual-purpose types, hybrid parents to develop dwarf hybrids for mechanized harvesting and fodder purpose hybrids with high recovery ability (for multicut forage purpose) in a range of maturity (70 to 85 days to $50 \%$ flowering) has been the major focus. Focus is also there on forage varieties amenable for both singleand multi-cuts to meet the needs of farmers and dairy Industry.

Considering that Caudatum race has been exploited extensively for diversification of hybrid parents at ICRISAT, and elsewhere, greater emphasis was given for the use of other races (durra and guinea ) for hybrid parents' development since 2000 at ICRISAT, Patancheru. Availability of cytoplasmic-nuclear male sterility (CMS) system, higher heterosis \% in the improved hybrids, and strong private sector presence facilitated the development of improved hybrids in large part of the globe. In addition to the widely used Milo-cytoplasm $\left(\mathrm{A}_{1}\right)$, cytoplasmic male-sterile lines are also available in $\mathrm{A}_{2}, \mathrm{~A}_{3}, \mathrm{~A}_{4}, \mathrm{~A}_{4} \mathrm{M}$, $\mathrm{A}_{4} \mathrm{VZM}, \mathrm{A}_{4} \mathrm{G} 1, \mathrm{~A}_{5}, \mathrm{~A}_{6}, 9 \mathrm{E}$ and $\mathrm{KS}$ cytoplasms [17-23]. Considering the restoration frequency, hybrid performance and comparable $A_{1}$ and $A_{2} C M S$ effects for grain yield and resistance to shoot fly and grain mold, it is advantageous to use $\mathrm{A}_{2} \mathrm{CMS}$ system for developing hybrid parents, among the alternate cytoplasms available. This not only increases the cytoplasmic diversity but reduces the possibility of epidemics occurrence when a single source of cytoplasm is used. This has been a major priority in hybrid seed parents' development at ICRISAT. As a result of concerted efforts, a total of 85 new race-specific A-/B-lines (39 $\mathrm{A}_{1}$ and $46 \mathrm{~A}_{2}$ CMS-systems based) have been developed in last 10 years (Table 2).

The grain yield potential of some of the improved Blines $\left(\mathrm{A}_{2}\right)$ was significantly higher than the control 296B (Table 3).

\subsection{Shoot Fly Resistance}

Shoot fly is a major problem in late-sown crop in regions/years with erratic rains. At ICRISAT, interlardfishmeal technique has been used for screening against shoot fly to develop shoot fly resistant hybrid parents [24]. While breeding for shoot fly resistance, resistant sources in desirable agronomic background (ICSV 702, ICSH 705, ICSV 708, PS 21318, PS 30715-1 and PS 35805) as well as other sources (IS 18551) were used in crossing programs. Following trait-based pedigree breeding approach, a large number of shoot fly resistant seed parents for both rainy season (ICSA-/B-409 to ICSA-/B436) and post-rainy season adaptation (ICSA-/B-437 to ICSA-/B-463) were developed [25]. All these B-lines have been designated and characterized as per the Distinctness, Uniformity and Stability (DUS) test guidelines and their characteristics are available at ICRISAT website: http//www.icrisat.org/text/research/grep/homepage/ sorghum/breeding/main.htm, verified on 5 July 2011 [14]. More recently, new sources of resistance IS 923, IS 1057,

Table 2. The number of race-specific A-/B-lines developed at ICRISAT, Patancheru, India after year 2000.

\begin{tabular}{ccc}
\hline \multirow{2}{*}{ Race } & \multicolumn{2}{c}{ Number of A-/B-lines } \\
\cline { 2 - 3 } & $\mathrm{A}_{1}$ & $\mathrm{~A}_{2}$ \\
\hline Durra bold grain & 23 & 28 \\
Caudatum & 6 & 4 \\
Guinea & 10 & 5 \\
Feterita (Caudatum) & - & 9 \\
Total & 39 & 46 \\
\hline
\end{tabular}


Table 3. Performance of sorghum advanced B-lines ( $A_{2}$-cytoplasm based) at ICRISAT, Patancheru during 2010 rainy season.

S. No Origin Days to $50 \%$ flowering Plant height $(\mathrm{m})$

Panicle grain mold rating score

( 1 = no mold, $9 \geq 90 \%$ )
Grain yield $\left(\mathrm{t} \cdot \mathrm{ha}^{-1}\right) \quad$ 100-seed weight $(\mathrm{g})$

\begin{tabular}{ccccccc}
\hline 1 & SP 09 27915 & 76 & 2 & 2.7 & 2.77 & 2.7 \\
2 & ABT 6 & 74 & 1.9 & 2 & 2.23 & 2.6 \\
3 & SP 09 27943 & 79 & 2 & 2.3 & 2.06 & 2.3 \\
4 & SP 09 27917 & 73 & 2 & 3 & 1.88 & 2.4 \\
5 & SP 09 27911 & 73 & 1.9 & 2.7 & 1.73 & 2.6 \\
6 & PBTA2 21 & 73 & 2.1 & 2.3 & 1.66 & 2.8 \\
7 & PBTA2 9 & 69 & 1.5 & 5 & 1.53 & 2.1 \\
8 & SP 09 27939 & 79 & 2 & 3 & 1.52 & 2 \\
9 & SP 09 27949 & 77 & 1.8 & 3 & 1.46 & 2.7 \\
20 & 296B & 74 & 1.5 & 3.3 & 1.49 & 2.1 \\
& Grand Mean & 76 & 1.8 & 3.1 & 1.52 & 2.4 \\
& CV & 2.7 & 5.3 & 19 & 16.9 & 13.8 \\
& LSD & 3.43 & 0.16 & 0.97 & 0.42 & 0.55 \\
\hline
\end{tabular}

IS 1071 , IS 1082, IS 1096, IS 2394, IS 4663, IS 5072, IS 18369, IS 4664, IS 5470 and IS 5636 are in use for development of shoot fly resistant hybrid parents. On comparing the $A_{1}$ and $A_{2}$ systems for shoot fly resistance, no significant differences were observed between $A_{1}$ and $A_{2}$ cytoplasms [26]. High yielding, shoot fly resistant hybrid parents were developed and heterotic hybrids produced using these parents. The need for having shoot fly resistance in both female and male parents for producing shoot fly resistant high yielding hybrids was demonstrated [27]. In sorghum, quantitative trait loci (QTL) governing various component traits contributing for shoot fly resistance have been identified and mapped in the parent IS 18551 [28] and CT Hash, ICRISAT, Personal communication). The QTL have been transferred to two cultivated backgrounds namely, BTx623 and 296B at ICRISAT (Hash CT, ICRISAT, Personal communication). These lines are currently being used to transfer shoot fly resistance in to elite sorghum hybrid parents. New B-lines with high grain yield and shoot fly resistance were identified during the 2008 rainy season at ICRISAT-Patancheru (Table 4).

\subsection{Grain Mold Tolerance}

Grain mold is one of the important biotic challenges for the rainy season sorghum. Both greenhouse and field screening techniques have been standardized by ICRISAT and partners for effective screening for grain mold resistance [16] and new sources of resistance were identified for use in breeding programs. Grain hardness, red pericarp and pigmented testa contribute to grain mold resistance [16]. In a study at ICRISAT, 156 grain mold tolerant/resistant lines were identified by screening 13,000 photoperiod-insensitive sorghum germplasm lines [29]. Resistance has been found mostly in colored grain sorghums with and without tannins and also in very few white-grain sorghums [29,30]. White grained sorghums are preferred for food use in India whereas colored grains are preferred in other parts of the world. Using the grain mold resistant germplasm sources, acouple of improved hybrid parents and varieties were developed [29]. Recent studies showed that there are no cytoplasmic differences between $A_{1}$ and $A_{2}$ cytoplasms for grain mold resistance and it is feasible to develop white pericarp grain mold resistant high yielding sorghum hybrids with stable per- 
Table 4. Performance of advanced sorghum B-lines for agronomic traits and shoot fly resistance in the 2008 rainy season at ICRISAT-Patancheru, India.

\begin{tabular}{ccccc}
\hline Genotype & $\begin{array}{c}\text { Days to 50\% } \\
\text { flowering }\end{array}$ & $\begin{array}{c}\text { Plant } \\
\text { height }(\mathrm{m})\end{array}$ & $\begin{array}{c}\text { Shoot fly } \\
\text { deadhearts }(\%)\end{array}$ & $\begin{array}{c}\text { Grain yield } \\
\left(\mathrm{t} \cdot \mathrm{ha}^{-1}\right)\end{array}$ \\
\hline ICSB 29001 & 70 & 1.4 & 38 & 3.51 \\
ICSB 29002 & 69 & 1.5 & 71 & 3.63 \\
ICSB 29003 & 70 & 1.6 & 40 & 3.57 \\
ICSB 29004 & 69 & 2.1 & 45 & 6.09 \\
ICSB 29005 & 68 & 1.5 & 46 & 5.33 \\
ICSB 29006 & 69 & 1.5 & 54 & 4.47 \\
ICSB 29017 & 68 & 1.5 & 33 & 4.50 \\
ABT 1007 & 68 & 1.6 & 39 & 4.52 \\
PBT 1004 & 69 & 1.8 & 53 & 4.29 \\
Controls & & & & \\
IS 18551 & 72 & 3 & 31 & 2.57 \\
296B & 70 & 1.5 & 59 & 4.11 \\
Swarna & 69 & 1.8 & 44 & 4.86 \\
Mean & 69 & 1.73 & 46.02 & 4.28 \\
SE ( \pm ) & 1.18 & 0.21 & 14.33 & 0.35 \\
CV (\%) & 2.95 & 21.33 & 23.93 & 14.00 \\
CD (5\%) & 3.47 & 0.63 & 4.20 & 1.00 \\
\hline & & & & \\
\hline
\end{tabular}

formance by using improved grain mold resistant hybrid parents, at least one of the parents being resistant to grain mold [31]. For identifying QTL for grain mold resistance, mapping populations (RILs) were developed (296 B $\times$ PVK 801; PVK $801 \times 296$ B) and the phenotyping of these populations for grain mold resistance is in progress. Recently, 14 B-lines with a grain yield of 1.9 to $2.6 \mathrm{t}^{\mathrm{ha}} \mathrm{ha}^{-1}$ and significantly superior to the check, $296 \mathrm{~B}\left(1.3 \mathrm{t} \cdot \mathrm{ha}^{-1}\right)$ for grain yield were developed and all these B-lines were tolerant to grain mold with panicle grain mold rating ranging from 2.0 to 3.7 compared to the susceptible check, 296B (PGMR: 4.3 on 1 to 9 scale where $1=$ no molds and $9 \geq 90 \%$ grain surface area covered with molds) (ICRISAT Archival Report 2009 http://www.icrisat.org/ icrisat-archival-reports.htm verified on 5th July 2011).

\subsection{Drought Tolerance}

Four growth stages in sorghum have been considered as vulnerable to drought: germination and seedling emergence, postemergence or early seedling stage, midseason or pre-flowering, and terminal or postflowering. Terminal drought is the most limiting factor for sorghum pro- duction worldwide. In sub-Saharan Africa, drought at both seedling establishment and terminal stages is very common. In India, sorghum is grown during both rainy and postrainy seasons. The variable moisture availability at both pre-flowering and post-flowering stages during the rainy season can have severe impact on grain and biomass yield. Climatic variability and associated genotype $\times$ environment interactions do not permit clear definition of target environments. Opportunities to make progress in breeding for drought tolerance occur both in understanding the environmental control of crop growth and in developing simplified approaches to modeling effects of climate change [32].

Drought and/or heat stress at the seedling stage often results in poor emergence, plant death and reduced plant stands. Severe pre-flowering drought stress results in drastic reduction in grain yield. Post-flowering drought stress tolerance is indicated when plants remain green and fill grain normally. A stay-green trait has been associated with post-flowering drought tolerance in sorghum. Genotypes with the stay-green trait are also reported to be resistant to lodging and charcoal rot [33] (Figure 2).

Genetic enhancement of sorghum for drought tolerance would stabilize productivity and contribute to sustainability of production systems in drought-prone environments. The extent of grain yield losses due to drought stress depends on the stage of the crop and the timing, duration, and severity of drought stress. Sorghum responses to moisture stress at all four growth stages have been well characterized. Variation in these responses has been observed and found to be heritable [3]. Since the phenotypic responses of genotypes differing in drought tolerance can be masked if drought occurs at more than

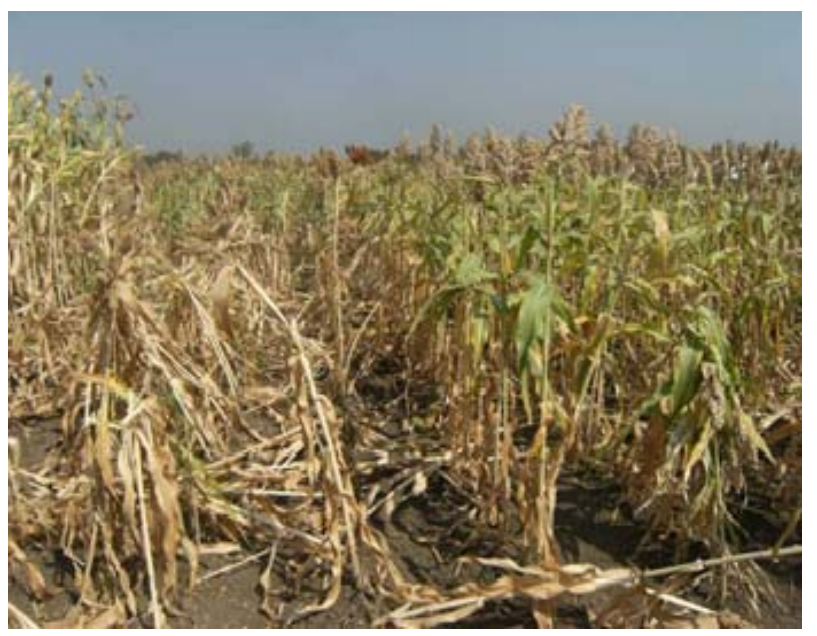

Figure 2. Expression of stay-green trait (in sorghum) under receding soil moisture conditions in a vertisol (photo courtesy: C Tom Hash, Santosh Deshpande and Vincent Vadez, ICRISAT). 
one stage, screening techniques have been developed to identify drought-tolerant genotypes at each of the growth stages, separately [34-40]. Of the several mechanisms to circumvent drought stress in sorghum, drought escape (related to shorter maturity durations), drought avoidance (maintenance of higher leaf water potential, LWP), and drought tolerance (related to greater osmotic adjustment, OA) are important and have been well characterized [3]. However, LWP and OA did not correlate well enough with grain yield in field conditions to merit selection based on them; in addition, screening techniques developed based on LWP and OA were not cost effective in sorghum breeding. Empirical screening based on imposing drought at various growth stages and measuring plant morphological and yield responses was the most effective approach. Long mesocotyl in seedling establishment and recovery from mid-season stress after release by rains are important traits that can be easily deployed in lines. The stay-green trait has been well exploited to enhance post-flowering drought tolerance in sorghum [3].

At ICRISAT, growth-stage-specific breeding for drought tolerance, which involves alternate seasons of screening in specific drought and well-watered environments, has been used to breed sorghum that can yield well in both high-yield-potential environments as well as in droughtprone environments [3]. Since hybrids have exhibited relatively better performance than open pollinated (OP) cultivars for grain yield under water-limited environments, hybrid cultivar development (including their parents) should be given strategic importance for enhancing sorghum production in water-scarce environments [3]. The progress in enhancing drought tolerance in sorghum through conventional approaches is limited by the quantitative inheritance of drought tolerance and yield coupled with the complexity of the timing, severity and duration of drought. Biotechnology appears to offer promising tools, such as marker-assisted selection, for genetic enhancement of drought tolerance in sorghum. Four stable and major QTLs were identified for the stay-green trait and are being introgressed through MAS into elite genetic backgrounds at ICRISAT, QDPI, Purdue University, and Texas A \& M University [3].

Integration of the sorghum genetic map developed from QTL information with the physical map will greatly facilitate the map-based cloning and precise dissection of complex traits such as drought tolerance in sorghum. Sorghum has a compact genome size $(2 \mathrm{n}=20)$ and can be an excellent model for identifying genes involved in drought tolerance to facilitate their use in other crops. It was reported that with respect to withstanding drought, sorghum has four copies of a regulatory gene that activates a key gene family which is present in a wide variety of plants. Sorghum also has several genes for proteins called expansins, which may be involved in helping sorghum to recover from droughts. In addition, it has 328 cytochrome P450 genes, which may help plants respond to drought stress, whereas rice has only 228 of these genes [5].

Some of the drought tolerant sources identified in sorghum at ICRISAT include Ajabsido, B35, BTx623, BTx642, BTx3197, El Mota, E36Xr16 8/1, Gadambalia, IS12568, IS22380, IS12543C, IS2403C, IS3462C, CSM63, IS11549C, IS12553C, IS12555C, IS12558C, IS17459C, IS3071C, IS6705C, IS8263C, ICSV 272, Koro Kollo, KS19, P898012, P954035, QL10, QL27, QL36, QL41, SC414-12E, Segaolane, TAM422, Tx430, Tx432, Tx2536, Tx2737, Tx2908, Tx7000 and Tx7078 (www.icrisat.org). ICRISAT has identified lines that are tolerant to drought at various growth stages (Table 5). Drought tolerance of M 35-1, a highly popular post-rainy season adapted landrace in India, has been amply demonstrated [41].

\section{Hybrid Parents with Postrainy Season Adaptation}

Post-rainy sorghums are very crucial for food and fodder security in the drought prone areas of India [43] as there is no alternative cereal grown during this season, which receives only $8 \%$ of the total annual rainfall. Due to excellent grain quality, post-rainy sorghums are mostly used as food. The grain productivity of post-rainy sorghum is very low as much of the cultivated area is under landraces that are poor grain yielders. Terminal drought stress is a major production constraint in the post-rainy season as the crop is grown on receding soil moisture after cessation of the rains. Low levels of heterosis for grain yield and low levels of shoot fly resistance were

Table 5. Sorghum germplasm and breeding lines tolerant to drought at specific growth stages, ICRISAT-Patancheru, India.

\begin{tabular}{cl} 
Growth stage & \multicolumn{1}{c}{ Drought tolerant sources/improved lines } \\
& IS 4405, IS 4663, IS 17595 and IS 1037, \\
Seedling emergence & $\begin{array}{l}\text { VZM1-B and 2077 B, IS 2877, IS 1045, D } \\
\text { 38061, D 38093, D 38060, ICSV 88050, ICSV } \\
\text { 88065 and SPV 354 }\end{array}$ \\
& \\
Early seedling & ICSB 3, ICSB 6, ICSB 11 and ICSB 37, ICSB \\
& 54 and ICSB 88001 \\
& \\
& DKV 1, DKV 3, DKV 7, DJ 1195, ICSV 272, \\
Mid-season & ICSV 273, ICSV 295, ICSV 378, ICSV 572, \\
& ICSB 58 and ICSB 196 \\
& \\
Terminal drought $36-1$, DJ 1195, DKV 3, DKV 4, DKV 17, & DKV 18, ICSB 17
\end{tabular}


observed in post-rainy season hybrids. Therefore, most farmers use either landraces or open pollinated varieties (OPVs) for Post-rainy season sowings [44]. Considering that photo- period sensitivity and low temperature tolerance during flowering, terminal drought tolerance, and grain quality traits are critical for post-rainy season crop, ICRISAT is engaged in developing hybrid parents by involving several post-rainy season adapted landraces $(\mathrm{M}$ 35-1, Gidda Maldandi, DSH 128, E 36-1, Barsizoot, Dagadi Sholapur, Dagadi local, Amaravathi local, M 35-1 selection bulks, etc.) and elite varieties and B-lines with good grain quality traits in the crossing program. Promising B-lines with higher yield and good grain quality were developed (Table 6).

\section{Grain Micronutrient Density}

Biofortification (increasing the grain $\mathrm{Fe}$ and $\mathrm{Zn}$ status through genetic means) complements the on-going efforts to address hidden malnutrition which is rampant in Sub-Saharan Africa and South Asia [45,46]. It is one of the cheapest and sustainable options to combat the malnutrition in predominantly sorghum eating populations [47]. Based on sorghum grain consumption levels, nutriaent retention in grain storage and processing, and nutrient bioavailability ICRISAT targeted $70 \mathrm{ppm} \mathrm{Fe}$ and $40 \mathrm{ppm}$ $\mathrm{Zn}$ contents in grain for addressing micronutrient malnutrition in populations who depend predominantly on sorghum for their nutrient requirements [47]. ICRISAT un-

Table 6. Performance of post-rainy sorghum advanced B-lines in sorghum ( $\mathrm{A}_{1}$-cytoplasm based) at ICRISAT, Patancheru during 2009 postrainy season.

\begin{tabular}{|c|c|c|c|c|c|c|}
\hline S. No & Entry & Days to $50 \%$ flowering & Plant height (m) & Grain luster score ${ }^{*}$ & Grain yield $\left(\mathrm{t} \cdot \mathrm{ha}^{-1}\right)$ & 100 grain weight $(\mathrm{g})$ \\
\hline 1 & SP 54457-1 & 74 & 1.5 & 2.0 & 6.3 & 3.2 \\
\hline 2 & SP 93037 & 81 & 1.3 & 2.0 & 5.6 & 2.3 \\
\hline 3 & SP 92919 & 72 & 1.4 & 2.0 & 5.0 & 2.6 \\
\hline 4 & SP 92931 & 73 & 1.4 & 2.0 & 4.7 & 2.7 \\
\hline 5 & SP 92929 & 76 & 1.1 & 2.0 & 4.7 & 2.5 \\
\hline 6 & SP 93035 & 79 & 1.3 & 2.0 & 4.7 & 2.4 \\
\hline 7 & SP 92927 & 72 & 1.4 & 2.0 & 4.6 & 2.7 \\
\hline 8 & SP 92925 & 73 & 1.3 & 2.0 & 4.4 & 2.6 \\
\hline 9 & SP 92923 & 72 & 1.4 & 2.0 & 4.4 & 2.6 \\
\hline 10 & SP 92939 & 76 & 1.2 & 2.0 & 4.4 & 2.6 \\
\hline 11 & SP 54425-1 & 74 & 1.3 & 3.0 & 4.3 & 3.3 \\
\hline 12 & SP 92921 & 72 & 1.4 & 2.0 & 4.2 & 2.5 \\
\hline 13 & SP 93019 & 71 & 1.2 & 2.7 & 3.5 & 3.3 \\
\hline 14 & ICSB 52 (Check) & 71 & 1.5 & 3.0 & 5.0 & 4.0 \\
\hline \multirow[t]{5}{*}{15} & 296 B (Check) & 79 & 1.1 & 3.0 & 3.4 & 3.0 \\
\hline & Mean & 74 & 1.3 & 2.2 & 4.6 & 2.8 \\
\hline & $\mathrm{CV}$ & 1.3 & 4.5 & 6.6 & 10.9 & 5.5 \\
\hline & LSD & 2 & 0.1 & 0.3 & 0.8 & 0.3 \\
\hline & PVALUE & 0 & 0 & 0 & 0 & 0 \\
\hline
\end{tabular}

("Luster score taken on a scale where $1=$ highly lustrous and $5=$ dull grain color). Small quantities of all these materials can be obtained from ICRISAT on request. 
dertook screening of core germplasm accessions to identify lines with high $\mathrm{Fe}$ and $\mathrm{Zn}$ contents. A total of 2267 core germplasm accessions were screened and promising donors identified under the HarvestPlus Challenge Programme [48]. Significant positive association between grain $\mathrm{Fe}$ and $\mathrm{Zn}$ contents and no significant association between grain $\mathrm{Fe}$ and $\mathrm{Zn}$ contents and agronomic traits were observed [49]. ICRISAT is developing the hybrid parents with high grain $\mathrm{Fe}$ and $\mathrm{Zn}$ contents in order to develop and disseminate sorghum hybrids with high micronutrient density. A total of 66 commercial sorghum cultivars developed by public sector and private sector partner organizations in India were assessed for grain $\mathrm{Fe}$ and $\mathrm{Zn}$ contents and promising cultivars identified [47] (Table 7).

\section{Sweet Sorghum for Ethanol Andanimal Feed}

Sweet sorghum is a multi-purpose crop that yields food, fodder and fuel. It is being used for syrup and ethanol production in U.S.A (http://nssppa.org/Sweet_Sorghum FAQs.html verified on 12th July 2011) EU (http://essecommunity.eu/ verified on 12th July 2011), China, Philippines, Mali, India and other countries. ICRISAT, under its BioPower strategy is working on sweet sorghum improvement for bioethanol production without unduly compromising the food or fodder use of the crop. Ethanol feedstock CSH 22SS, the first sweet sorghum hybrid released in India, was based on the ICRISAT-bred female parent ICSA 38. Strategic research at Indian national program and ICRISAT indicated that ethanol production in Indiausing sweet sorghum is cost-effective and its cultivation gives $23 \%$ additional income to farmers compared to the grain sorghum [50]. There are minimal food-fuel tradeoffs in sweet sorghum but season-specificity exists. Hybrids are the cultivar options, as hybrids are high-yielding, flower early and less photoperiodsensitive compared to the varieties. ICRISAT, along with

Table 7. Mean performance of the commercial sorghum cultivars (Set I) for grain Fe and Zn contents at ICRISATPatancheru, India during 2008 and 2009 postrainy seasons.

\begin{tabular}{|c|c|c|c|c|c|c|c|}
\hline \multirow{2}{*}{ Hybrid name } & \multirow{2}{*}{ Seed source } & \multicolumn{3}{|c|}{ Fe content $\left(\mathrm{mg} \cdot \mathrm{kg}^{-1}\right)$} & \multicolumn{3}{|c|}{$\mathrm{Zn}$ content $\left(\mathrm{mg} \cdot \mathrm{kg}^{-1}\right)$} \\
\hline & & 2008 & 2009 & Mean & 2008 & 2009 & Mean \\
\hline NSH 703 & Nuziveedu Seeds, Hyderabad & 50 & 38 & 44 & 36 & 28 & 32 \\
\hline GK 4035 & Ganga Kaveri Seeds, Hyderabad & 57 & 31 & 44 & 46 & 19 & 33 \\
\hline Mahabeej 703 & MSSCL, Akola & 53 & 33 & 43 & 36 & 22 & 29 \\
\hline NSH 702 & Nuziveedu Seeds, Hyderabad & 49 & 37 & 43 & 37 & 28 & 32 \\
\hline 8562 & Bayer Bio Sc., Hyderabad & 51 & 31 & 41 & 37 & 23 & 30 \\
\hline Mahabeej 704 & MSSCL, Akola & 48 & 31 & 40 & 34 & 19 & 26 \\
\hline KDSH 1179 & Krishidhan Seeds, Jalna & 48 & 30 & 39 & 31 & 22 & 27 \\
\hline BSH 45 & Biostadt Mh Seeds, Aurangabad & 48 & 29 & 39 & 32 & 22 & 27 \\
\hline Madhura-SS hybrid & Nimbkar Seeds, Paltan & 52 & 25 & 39 & 43 & 21 & 32 \\
\hline Mahabeej 7 & MSSCL, Akola & 52 & 25 & 39 & 33 & 18 & 26 \\
\hline GK 4009 & Ganga Kaveri Seeds, Hyderabad & 46 & 30 & 38 & 36 & 17 & 27 \\
\hline Hi-jowar 52 & Biostadt Mh Seeds, Aurangabad & 42 & 33 & 38 & 28 & 22 & 25 \\
\hline PSV 2 (variety) & ARS, Palem & 47 & 28 & 38 & 36 & 16 & 26 \\
\hline CSH 25 & MAU, Parbhani & 53 & 27 & 37 & 35 & 19 & 25 \\
\hline 8340 & Bayer Bio Sc., Hyd & 47 & 27 & 37 & 29 & 20 & 25 \\
\hline KDSH 209 & Krishidhan Seeds, Jalna & 48 & 28 & 36 & 31 & 22 & 26 \\
\hline PSV 1 (variety) & ARS, Palem & 47 & 26 & 36 & 31 & 17 & 24 \\
\hline BSH 47 & Biostadt Mh seeds, Aurangabad & 42 & 28 & 35 & 26 & 19 & 23 \\
\hline GK 4044 & Ganga Kaveri Seeds, Hyderabad & 43 & 26 & 33 & 32 & 16 & 22 \\
\hline 8568 & Bayer Bio Sc., Hyderabad & 37 & 23 & 30 & 29 & 17 & 23 \\
\hline \multicolumn{8}{|l|}{ Controls } \\
\hline PVK 801 (variety) & & 55 & 30 & 43 & 41 & 20 & 30 \\
\hline CSH 16 (hybrid) & & 50 & 32 & 41 & 34 & 22 & 28 \\
\hline Mean & & 48 & 29 & 39 & 34 & 20 & 27 \\
\hline $\mathrm{SE} \pm$ & & 2.86 & 1.85 & 2.76 & 2.09 & 1.44 & 2.00 \\
\hline $\mathrm{CD}(5 \%)$ & & 8.39 & 5.27 & 7.84 & 6.13 & 4.10 & 5.68 \\
\hline
\end{tabular}


Table 8. Nitrogen, neutral detergent fiber (NDF), in vitro digestibility (all in \% of dry matter) and mega joule (MJ) of metabolizable energy content and voluntary feed intake and changes in live weight in bulls fed a marketed commercial sorghum stover-based feed block (CFB), an experimental sweet sorghum bagasse/stripped leaves-based feed block (SLB) and sorghum stover of the type used in the CFB.

\begin{tabular}{cccccccc}
\hline Diets & Nitrogen (\%) & NDF (\%) & Iv Dig. (\%) & ME (MJ/kg) & Intake (kg/d) & Intake (g/d/kg LW) & Weight changes (kg/d) \\
\hline CFB & $1.81^{\mathrm{a}}$ & $56.1^{\mathrm{a}}$ & $57.5^{\mathrm{a}}$ & $8.21^{\mathrm{a}}$ & $7.31^{\mathrm{a}}$ & $35^{\mathrm{a}}$ & $0.82^{\mathrm{a}}$ \\
SLB & $1.65^{\mathrm{b}}$ & $56.2^{\mathrm{a}}$ & $54.6^{\mathrm{b}}$ & $7.77^{\mathrm{b}}$ & $7.52^{\mathrm{a}}$ & $37^{\mathrm{a}}$ & $0.73^{\mathrm{a}}$ \\
Sorghum stover & $0.45^{\mathrm{c}}$ & $70.2^{\mathrm{b}}$ & $50.5^{\mathrm{b}}$ & $7.30^{\mathrm{b}}$ & $2.31^{\mathrm{b}}$ & $13^{\mathrm{b}}$ & $-0.38^{\mathrm{b}}$ \\
\hline
\end{tabular}

its partners, is working on sweet sorghum ethanol value chain development including the supply chain management through a combination of centralized and decentralized models for commercial ethanol production [51]. Sweet sorghum when fed directly as forage was found to have high daily intake and higher digestibility in large ruminants (cows and buffaloes) [52]. No significant differences were observed in the intake or body weight of animals when bagasse and stripped leaves feed blocks were used to feed the ruminants indicating that sweet sorghum bagasse (after extraction of juice) can be used as animal feed without chemical or physical upgrading (Table 8) [53].

\section{Future Plans}

In addition to the biotic and abiotic challenges, presumed climate change effects influence the sorghum area and its importance globally. Climate change will modify the length of the growing period across the sorghum regions, but this can be mitigated by the re-targeting and re-deployment of existing germplasm. Predicted temperature increases, through their effect on increasing rate of crop development, will have greater negative impact on crop production than the relatively small $( \pm 10 \%)$ changes in rainfall that are predicted to occur. Yield gap analyses at ICRISAT and elsewhere have shown that the negative impacts of climate change can be largely mitigated through greater adoption of improved crop, soil and water management innovations by farmers and better targeted crop improvement approaches by researchers, more explicitly focused on adaptation to climate change. Keeping all these points in view, crop improvement research in sorghum need to beoriented towards genetic and cytoplasmic diversification for high yield and large grain, striga, shoot fly and grain mold resistance, drought, acid soil and salinity tolerance, postrainy season adaptation, sweet stalk traits, and grain micronutrient density. The grain and stover quality attributes need special attention in sorghum improvement programs to enhance the market value. More collaboration is required between ICRISAT and NARS partners across the globe in this endeavor. Harnessing the synergies of public- and privatesector agencies assume higher importance to ensure better impacts of genetic enhancement in farmers' fields.

\section{REFERENCES}

[1] B. V. S. Reddy, A. A. Kumar and P. S. Reddy, "Recent Advances in Sorghum Improvement Research at ICRISAT," Kasetsart Journal: Natural Science, Vol. 44, 2010, pp. 499-506.

[2] B. V. S. Reddy, A. A. Kumar, S. Ramesh and P. S. Reddy, "Breeding Sorghum for Coping with Climate Change," In: S. S. Yadav, R. Redden, J. L. Hatfield and H. LotzeCampen, Eds., Crop Adaptation to Climate Change, John Wiley \& Sons Inc., Iowa, 2011, pp. 326-339.

[3] Z. Z. Nagy, F. Tuba, Z. Soldos and L. Erdei, " $\mathrm{CO}_{2}$-Exchange and Water Relation Responses of Sorghum and Maize during Water and Salt Stress," Journal of Plant Physiology, Vol. 145, No. 4, 1995, pp. 539-544.

[4] B. V. S. Reddy, S. Ramesh, P. S. Reddy and A. A. Kumar, "Genetic Enhancement for Drought Tolerance in Sorghum," Plant Breeding Reviews, Vol. 31, 2009, pp. 189-222. doi:10.1002/9780470593783.ch3

[5] A. H. Paterson, J. E. Bowers and R. Bruggmann, "The Sorghum bicolor Genome and the Diversification of Grasses," Nature, Vol. 457, 2009, pp. 551-556. doi:10.1038/nature07723

[6] A. H. Paterson, "The Weediness of Wild Plants-Molecular Analysis of Genes Influencing Dispersal and Persistence of Johnson Grass, Sorghum Halepense (1) pers," Proceedings of the National Academy of Sciences of the United States of America, Vol. 92, 1995, pp. 6127-6131. doi:10.1073/pnas.92.13.6127

[7] P. Cooper, K. P. C. Rao, P. Singh, J. Dimes, P. S. Traore, K. Rao, P. Dixit and S. J. Twomlow, "Farming with Current and Future Climate Risk: Advancing a 'Hypothesis of Hope' for Rainfed Agriculture in the Semi-Arid Tropics," E-Journal of SAT Agricultural Research, Vol. 7, No. $1,2009$.

[8] ICRISAT Strategic Plan to 2020, "Inclusive MarketOriented Development for Smallholder Farmers in the Tropical Drylands," International Crops Research Institute for the Semi-Arid Tropics (ICRISAT), Patancheru, 2010, p. 60.

[9] M. C. S. Bantilan, U. K. Deb, C. L. L. Gowda, B. V. S. Reddy, A. B. Obilana and R. E. Evenson, "Sorghum Genetic Enhancement Research Process, Dissemination and Impacts," International Crops Research Institute for the Semi-Arid Tropics, Patancheru, 2004, p. 320.

[10] ICRISAT, "Medium-Term Plan 1994-1998," International Crops Research Institute for the Semi-Arid Tropics, Patancheru, 1992. 
[11] A. B. Obilana, E. S. Monyo and S. C. Gupta, "Impact of Genetic Improvement in Sorghum and Pearl Millet: Developing Country Experiences," Proceedings of the International Conference on Genetic Improvement of Sorghum and Pearl Millet, Lubbock, 22-27 September 1996, pp. 119-141.

[12] B. V. S. Reddy, A. A. Kumar, P. S. Reddy and M. Elangovan, "Sorghum Germplasm: Diversity and Utilization," In: B. V. S Reddy, S. Ramesh, A. A. Kumar and C. L. L. Gowda, Eds., Sorghum Improvement in the New Millennium, International Crops Research Institute for the Semi-Arid Tropics, Patancheru, 2008, pp. 153-169.

[13] S. A. Eberhart, P. J. Bramel-Cox and K. E. Prasada Rao, "Preserving Genetic Resources," Proceedings of the International Conference on Genetic Improvement of Sorghum and Pearl Millet, Lubbock, 22-27 September 1996, pp. 25-41.

[14] B. V. S. Reddy, H. C. Sharma, R. P. Thakur, S. Ramesh and A. A. Kumar, "Characterization of ICRISAT-Bred Sorghum Hybrid Parents," International Sorghum and Millets Newsletter, Vol. 48, Special Issue, 2007, pp. $1-123$.

[15] H. C. Sharma, V. R. Bhagwat and P. G. Padmaja, "Techniques to Screen Sorghums for Resistance to Insect Pests," In: B. V. S. Reddy, S. Ramesh, A. A. Kumar and C. L. L. Gowda, Eds., Sorghum Improvement in the New Millennium, International Crops Research Institute for the Semi-Arid Tropics, Patancheru, 2008, pp. 31-49.

[16] R. P. Thakur, B. V. S. Reddy, S. Indira, V. P. Rao, S. S. Navi, X. B. Yang and S. Ramesh, "Sorghum Grain Mold," International Crops Research Institute for the Semi-Arid Tropics, Patancheru, No. 72, 2006, p. 32.

[17] K. F. Schertz and D. R. Pring, "Cytoplasmic Male Sterility Systems in Sorghum," Sorghum in the Eighties, In: L. R. House, L. K. Mughogho and J. M. Peacock, eds., International Crops Research Institute for the Semi-Arid Tropics, Patancheru, 1982, pp. 373-383.

[18] K. F. Schertz, A. Sotomayor-Rios and S. Torres-Cardona, "Cytoplasmic-Nuclear Male Sterility: Opportunities in Breeding and Genetics," Proceedings of Grain Sorghum Reseasrch Utility Conference, Vol. 16, 1989, pp. 175186.

[19] T. Nagur, "Studies on Fertility Restoration and Combining Ability in Relation to Genetic Diversity and Cytoplasmic Constitution in Sorghum," Ph.D. Dissertation, Tamil Nadu Agricultural University, Coimbatore, 1971.

[20] K. F. Schertz, S. Sivaramakrishnan, W. W. Hanna, J. Mullet, Y. Sun, U. R. Murty, D. R. Pring, K. N. Rai and B. V. S. Reddy, "Alternate Cytoplasms and Apomixes of Sorghum and Pearl Millet," Proceedings of International Conference on Genetic Improvement of Sorghum and Pearl Millet, Lubbock, 22-27 September 1996, pp. 213-223.

[21] N. G. P. Rao, D. P. Tripathi and B. S. Rana, "Genetic Analysis of Cytoplasmic Systems in Sorghum," Indian Journal of Human Genetics, Vol. 44, 1984, pp. 48-49.

[22] J. V. Worstell, H. J. Kidd and K. C. Schertz, "Relationships among Male Sterility Inducing Cytoplasms of Sor- ghum," Crop Science, Vol. 24, No. 1, 1984, pp. 186-189. doi:10.2135/cropsci1984.0011183X002400010044x

[23] G. W. Xu, Y. X. Cui, K. F. Schertz and G. E. Hart, "Isolation of Mitochondrial DNA Sequences That Distinguish Male-Sterility Inducing Cytoplasms in Sorghum bicolor (L.) Moench," Theoretical and Applied Genetics, Vol. 90, No. 7-8, 1995, pp. 1180-1187. doi:10.1007/BF00222941

[24] K. F. Nwanze, "Screening for Resistance to Sorghum Shoot Fly," In: H. C. Sharma, F. Singh and K. F. Nwanze, Eds., Plant Resistance to Insects in Sorghum, International Crops Research Institute for the Semi-Arid Tropics, Patancheru, 1997, pp. 35-37.

[25] B. V. S. Reddy, P. Rao and U. K. Deb, "Global Sorghum Genetic Enhancement Processes at ICRISAT," In: M. C. S. Bantilan, U. K. Deb, C. L. L. Gowda, B. V. S. Reddy, A. B. Obilana and R. E. Evenson, Eds., Sorghum Genetic Enhancement: Research Process, Dissemination and Impacts, International Crops Research Institute for the Semi-Arid Tropics, Patancheru, 2004, pp. 65-102.

[26] B. V. S. Reddy, S. Ramesh, P. S. Reddy and A. A. Kumar, "Comparison of $\mathrm{A}_{1}$ and $\mathrm{A}_{2}$ Cytoplasmic Male-Sterility for Combining Ability in Sorghum (Sorghum bicolor (L.) Moench)," Indian Journal of Genetics and Plant Breeding, Vol. 69, No. 3, 2009, pp. 199-204.

[27] A. A. Kumar, B. V. S. Reddy, H. C. Sharma and B. Ramaiah, "Shoot Fly (Atherigona soccata) Resistance in Improved Grain Sorghum Hybrids," E-Journal of SAT Agricultural Research, Vol. 6, No. 1, 2008.

[28] K. Satish, G. Srinivas, R. Madhusudhana, P. G. Padmaja, R. N. Reddy, S. M. Mohan and N. Seetharama, "Identification of Quantitative Trait Loci for Resistance to Shoot Fly in Sorghum [Sorghum bicolor (L.) Moench]," Theoretical and Applied Genetics, Vol. 119, No. 8, 2009, pp. 1425-1439. doi:10.1007/s00122-009-1145-8

[29] R. Bandyopadhyay, L. K. Mughogho and K. E. Prasada Rao, "Sources of Resistance to Sorghum Grain Molds," Plant Disease, Vol. 72, 1988, pp. 504-508. doi:10.1094/PD-72-0504

[30] R. Bandyopadhyay, J. W. Stenhouse, S. D. Singh and B. V. S. Reddy, "Sorghum Grain Mold: Current Status," In: C. L. L. Gowda and J. W. Stenhouse, eds., Strengthening Sorghum Research Collaboration in Asia: Report of the Asian Sorghum Scientists' Meeting, International Crops Research Institute for the Semi-Arid Tropics, Patancheru, 1998, pp. 19-21.

[31] A. A. Kumar, B. V. S. Reddy, R. P. Thakur and B. Ramaiah, "Improved Sorghum Hybrids with Grain Mold Resistance," E-Journal of SAT Agricultural Research, Vol. 6, No. 1, 2008.

[32] F. R. Bidinger, G. L. Hammer and R. C. Muchow, "The Physiological Basis of Genotype by Environment Interaction in Crop Adaptation," In: M. Cooper and G. L. Hammer, Eds., Plant Adaptation and Crop Improvement, CAB International, Wallingford, 1996, pp. 329-347.

[33] B. V. S. Reddy, B. Ramaiah and A. A. Kumar, "Evaluation of Sorghum Genotypes for Stay-Green Trait and Grain Yield," E-Journal of SAT Agricultural Research, 
Vol. 3 (Suppl. 1), 2007.

[34] B. V. S. Reddy, "Genetic Improvement for Drought Resistance in Sorghum: A Plant Breeder's Viewpoint," Genetic Improvement for Drought Resistance, Proc. Discussion Series of Drought Research Seminar Forums. ICRISAT, Patancheru, 1986. pp. 28-32.

[35] A. Blum, J. Mayer and G. Golan, "Agronomic and Physiological Assessments of Genotypic Variation for Drought Resistance in Sorghum," Australian Journal of Agriculture Research, Vol. 40, 1989, pp. 49-61. doi:10.1071/AR9890049

[36] R. C. Muchow, F. R. Bidinger and G. L. Hammer, “Targeting Sorghum Improvement in Drought-Prone Environments: Approaches and Progress," In: Proceedings of the International Conference on Genetic Improvement of Sorghum and Pearl Millet, Lubbock, 1996, pp. 429-442.

[37] I. G. Haussmann, A. B. Obilana and A. Blum, "Hybrid Performance of Sorghum and Its Relationship to Morphological and Physiological Traits under Variable Drought Stress in Kenya," Plant Breeding, Vol. 117, No. 3, 1998, pp. 223-229. doi:10.1111/j.1439-0523.1998.tb01930.x

[38] A. K. Borrell, G. L. Hammar and R. O. Henzell, "Does Maintaining Green Leaf Area in Sorghum Improve Yield under Drought? II. Dry Matter Production and Yield," Crop Science, Vol. 40, No. 4, 2000a, pp. 1037-1048. doi:10.2135/cropsci2000.4041037x

[39] A. K. Borrell, G. L. Hammar and A. C. L. Douglas, "Does Maintaining Green Leaf Area in Sorghum Improve Yield under Drought? I. Leaf Growth and Senescence," Crop Science, Vol. 40, No. 4, 2000b, pp. 1026-1037. doi:10.2135/cropsci2000.4041026x

[40] K. Harris, P. K. Subudhi and A. Borrell, "Sorghum Stay Green QTL Individually Reduce Post-Flowering Drou ght-Induced Leaf Senescence," Journal of Experimental Botany, Vol. 58, No. 2, 2007, pp. 327-338. doi:10.1093/jxb/erl225

[41] N. Seetharama, B. V. S. Reddy and J. M. Peacock, "Sorghum Improvement for Drought Resistance in Crops with Emphasis on Rice," International Rice Research Institute (IRRI), Manila, 1982, pp. 317-338.

[42] ICRISAT, Annual Report, 1981, ICRISAT, Patancheru, 1982, pp. 1-31.

[43] Anonymous, Progress Report 2000-2001, Development of hybrids, Rabi sorghum (NATP MM project), Group meeting, Hyderabad, 16-18 October 2001, pp 11-14.

[44] P. S. Reddy, B. V. S. Reddy and A. A. Kumar, "M 35-1 Derived Sorghum Varieties for Cultivation during the Postrainy Season," E-Journal of SAT Agricultural Research, Vol. 7, No. 1, 2009.
[45] J. V. Meenakshi, N. L. Johnson, V. M. Manyong, H. Degroote, J. Javelosa, D. R. Yanggen, F. Naher, C. G. J. Garcia and E. Meng, "How Cost-Effective Is Biofortification in Combating Micronutrient Malnutrition? An exante Assessment," World Development Report, Vol. 38, No. 1, 2010, pp. 64-75. doi:10.1016/j.worlddev.2009.03.014

[46] H. E. Bouis, C. Hotz, B. McClafferty, J. V. Meenakshi and W. H. Pfeiffer, "Biofortification: A New Tool to Reduce Micronutrient Malnutrition," Food and Nutrition Bulletin, Vol. 32, Supplement 1, 2011, pp. 31S-40S.

[47] A. A. Kumar, B. V. S. Reddy, K. L. Sahrawat and B. Ramaiah, "Combating Micronutrient Malnutrition: Identification of Commercial Sorghum Cultivars with High Grain Iron and Zinc," E-Journal of SAT Agricultural Research, Vol. 8, No. 1, 2010.

[48] A. A. Kumar, B. V. S. Reddy, B. Ramaiah, P. Sanjana Reddy, K. L. Sahrawat and H. D. Upadhyaya,"Genetic Variability and Plant Character Association of Grain Fe and $\mathrm{Zn}$ in Selected Core Collections of Sorghum Germplasm and Breeding Lines," E-Journal of SAT Agricultural Research, Vol. 7, No. 1, 2009.

[49] P. S. Reddy, B. V. S. Reddy, A. A. Kumar, S. Ramesh, K. L. Sahrawat and P. V. Rao, "Association of Grain Fe and Zn Contents with Agronomic Traits in Sorghum," Indian Journal of Plant Genetic Resources, Vol. 23, No. 3, 2010, pp. 280-284.

[50] B. V. S. Reddy, S. Ramesh, A. A. Kumar, S. P. Wani, R. Ortiz, H. Ceballos and T. K. Sreedevi, "Bio-Fuel Crops Research for Energy Security and Rural Development in Developing Countries," Bio-Energy Research, Vol. 1, No. 3-4, 2008, pp. 248-258. doi:10.1007/s12155-008-9022-x

[51] A. A. Kumar, B. V. S. Reddy, C. R. Reddy, M. Blümmel, P. S. Rao, B. Ramaiah and P. S. Reddy, "Enhancing the Harvest Window for Supply Chain Management of Sweet Sorghum for Ethanol Production," E-Journal of SAT Agricultural Research, Vol. 8, No. 1, 2010.

[52] A. A. Kumar, B. V. S. Reddy, M. Blümmel, S. Anandan, Y. R. Reddy, C. R. Reddy, P. S. Rao and P. S. Reddy, "On-Farm Evaluation of Elite Sweet Sorghum Genotypes for Grain and Stover Yields and Fodder Quality," Animal Nutrition and Feed Technology, Vol. 10S, 2010, pp 6978.

[53] M Blümmel, S. S. Rao, S. Palaniswami, L. Shah and B. V. S. Reddy, "Evaluation of Sweet Sorghum (Sorghum bicolor (L) Moench) Used for Bio-Ethanol Production in the Context of Optimizing Whole Plant Utilization," Animal Nutrition and Feed Technology, Vol. 9, 2009, pp. 1-10. 